\title{
The European Policy Model Revision and the Challenge of Democracy
}

\section{Rosaria Rita Canale*}

Department of Economic Studies, Salvatore Vinci University of Naples Parthenope, Italy

\begin{abstract}
The theoretical underpinnings of the European Policy model are 1) the deterministic nature of the economic system; 2) the ability of financial markets to anticipate the future trend of the economy. The crisis denied the goodness of these two assumptions and revealed that the policy structure is unable to counter the crisis. PIIGS countries do not have short run tools to fill the gap with virtuous countries and national priorities appear to be overcome by European claims for budgetary discipline. The existence of a two speeds Europe seriously threaten the future existence of the currency union. In search for solutions national economists and politicians should consider a "new trilemma": the impossibility to have at the same time globalization, democracy and autonomous policy management. The challenge Europe as a whole faces is to build up a political project capable of managing globalization through policy action and at the same time preserve democracy.
\end{abstract}

Keywords: European monetary union; Economic policy; Crisis; Democracy

\section{Introduction}

The policy model, the European Union was built on, represents the most faithful implementation of the theoretical conclusions reached by the mainstream. These conclusions can be summarized, for the aim of this note, with the denial of the direct relationship between government spending and growth and of the active role of monetary policy in influencing the equilibrium income.

These conclusions affected almost all the advanced economies and conduced to an institutional structure

Based on:

1. Separation between fiscal and monetary policy

2. Fiscal policies to be managed within a general criterion of spending constraint

3. Monetary policy with the purpose of maintaining constant the price growth;

In Europe two elements were added:

1. A single monetary policy

2. Fiscal policy based on a strict budgetary discipline and left to the management of individual states.

This model showed its limits in dealing with situations such as those of the 2007's financial crisis [1]. Its underpinnings are two controversial hypotheses that in times of crisis -in particular a financial crisis - represent an oxymoron [2].

a) The deterministic nature of the economic system;

b) The ability of financial markets to anticipate the future trend of the economy.

According to the first hypothesis, in examining the working and the adjustment mechanisms of the economic system it is not necessary to consider the case of the occurrence of systemic shocks (i.e., affecting all countries contemporarily).

Following the second hypothesis - known as efficiency market hypothesis - financial markets are considered capable of assessing the various risks in order to prevent the excessive accumulation of debt, both public and private, by anticipating the future value of assets.

The crisis denied the goodness of these two assumptions and has been spreading negative real effects throughout the world through banks balance sheets, the higher financing costs and the fall of aggregate demand [3].

The crisis also highlighted the greater fragility of some countries in respect to others and made clear that the economic policy structure was designed unbalanced. Unbalanced with respect to some countries and unbalanced with respect to the role of monetary policy to which the fiscal policy is subordinated, rather than independently managed.

The so-called PIIGS countries - or GIPSI depending on whether you want to interpret their limits as "animal" or "racial" - do not have short run tools to bridge the gap with virtuous countries. They can just reduce domestic demand through wage and public sector cuts. These tools are likely to generate, in times of crisis, even worse results than the financial meltdown.

In this context the size of fiscal imbalances and the widening of spreads are a symptom of weakness rather than the cause itself (this seems to be proved by the fact that Spain debt / GDP ratio was lower than Germany). This situation generates a self-fulfilling mechanism [4]: the more the GDP falls, the more deficit and debt grow, and the more the PIIGS countries are forced to fiscal retrenchments to meet European requests. Lacking a monetary policy that can help them (given that the impressive injections of liquidity in the banking sector is not reducing the negative effect of the credit crunch) PIIGS countries, whatever their original sin, must bear huge costs, which, at the end, could even be completely useless.

However if the EMU's economic policy is showing its limits consensus has not yet found on how to manage the future of the continent. Many economists are now convinced that, by persevering in this direction the project of Monetary Union will eventually fail. Therefore rather to bear such high social costs, it would be better to grant autonomy to the national economic policy. This would give the advantage to return to a democratic mechanism, leaving decisions to

*Corresponding author: Rosaria Rita Canale, Associate professor, Department of Economic Studies, Salvatore Vinci University of Naples Parthenope, Italy, E-mail: rorita.canale@uniparthenope.it

Received July 08, 2012; Accepted July 11, 2012; Published July 13, 2012

Citation: Canale RR (2012) The European Policy Model Revision and the Challenge of Democracy. J Stock Forex Trad 1:e107. doi:10.4172/2168-9458.1000e107

Copyright: (c) 2012 Canale RR. This is an open-access article distributed under the terms of the Creative Commons Attribution License, which permits unrestricted use, distribution, and reproduction in any medium, provided the original author and source are credited. 
each individual country. This position finds consensus also among those who believe they are suffering from the inefficiencies of the peripheral countries on the other side there are those who believe that the alternative route is a political union. The true anomaly of the European Monetary Union is the non correspondence of the common currency to a single state: it derives the inability to cope with shocks as common problems.

In search for solutions national economists and politicians should consider a "new trilemma"1 [5]: the impossibility to have at the same time globalization, democracy and autonomous policy management. When a democracy faces globalization cannot use autonomously policy instruments to pursue its targets. A democracy can autonomously pursue its policy objectives if globalization is subject to constraints. Constraining globalization and closing national borders, for a small not self-sufficient country means to lose the power to pursue its objective, i.e. the degree of democracy.

Thus, who gives up building a political project in Europe as response to the challenges of globalization, must be aware that, in the attempt to sustain the domestic economy in crisis, will pay a price in terms of democracy. The challenge Europe as a whole faces is to build up a political project capable of managing globalization through policy action and at the same time preserve democracy.

\section{References}

1. De Grauwe P (2011) The Governance of a Fragile Eurozone. CEPS Working Document, No. 346, Maggio.

2. Bini Smaghi $L$ (2011) Regole e istituzioni di politica economica in tempi di crisi. Forum for EU-US Legal Economic Affairs, Roma.

3. Krugman $P$ (2010) Debt, deleveraging, and the liquidity trap.

4. De Grauwe P (2011) Balance budget fundamentalism, CEPS Commentaries.

5. Rodrick D (2011) The Globalization Paradox: Democracy and the Future of the World Economy, New York and London: W.W. Norton.

6. Obstfeld M (1995) International capital mobility in the 1990s, in P.B. Kenen, ed. Understanding interdependence: The macroeconomics of the open economy. Princeton, NJ: Princeton University Press. 